\title{
Floristic Diversity of the Natural Forests of Dimbokro Region, Centre-Eastern Côte d'Ivoire
}

\author{
Biagné Massa Rita, PhD student \\ Kouamé N'Guessan François, Associate Professor \\ Nangui Abrogoua University, UFR Nature Sciences and African Centre of \\ Excellence on Climate Change, Biodiversity and Sustainable Agriculture, \\ Côte d'Ivoire \\ N'Guessan Kouakou Edouard, Full Professor
}

Félix Houphouët Boigny University, UFR Biosciences, Côte d'Ivoire

Doi: 10.19044/esj.2018.v14n36p174 URL:http://dx.doi.org/10.19044/esj.2018.v14n36p174

\begin{abstract}
This study, carried out in three types of forest types (reserve, riparian and of plateaus) in a savannah and forest mosaic region of Côte d'Ivoire, aims to arise up the floristical characteristics of these natural forests. Trees and lianas with $\mathrm{DBH} \geq 10 \mathrm{~cm}$ were sampled into 30 plots of $50 \mathrm{mx} 20 \mathrm{~m}$ per forest type and named botanically. The floristic diversity and taxa distribution were analyzed using various coefficients and a Factorial Correspondence Analysis respectively. We found 89 species belonging to 77 genera and 36 families. The most abundant taxa were Verbenaceae family (43\%), LeguminosaeCaesalpinioideae subfamily (19\%), Leguminosae-Mimosoideae subfamily (6\%), Malvaceae family (6\%), Sapotaceae family (6\%), Moraceae family (4\%) and Leguminosae-Papilionoideae subfamily (3\%). Both riparian forests and forests of plateaus showed higher species richness and diversity and were similar for these parameters. Average species richness varied from 5 in forest reserve to 9 in both riparian forests and forests of plateaus respectively. Shannon-Weaner's diversity index was set between 0.832 in the forest reserves and 1.723 in the riparian forests while the equitability index of Pielou varied from 0.516 in the forest reserves to 0.789 in the riparian forests. The forest reserves and of plateaus showed similar spatial distribution of the woody plants with $\mathrm{DBH} \geq 10 \mathrm{~cm}$.
\end{abstract}

Keywords: Woody plants, richness and diversity, savannah and forest mosaic, West Africa 


\section{Introduction}

The destruction of the tropical forests causes a considerable reduction of the biodiversity in the world (Myers et al., 2000). Thus, it mainly modifies the microclimate within the forest fragments by a reduction in moisture and an increase in light availability (Heithecker et al., 2007; Laurance et al., 2008). The annual rate of deforestation was estimated at more than 6.5 million hectares between 1990 and 2015 (Myers et al., 2000; FAO, 2015). Due to poverty, the most important loss of forest surfaces was recorded in the developing countries (FAO, 2015).

In Côte d'Ivoire, the forest cover which amounted to 15 million hectares in 1900 (SODEFOR, 1996), is estimated today less than 2.7 million hectares (Païvinen et al., 1992; Chatelain et al., 2004; Kouamé, 2016). Dimbokro region is not in margin of this forest loss. Indeed, since 1950, cocoa and coffee were very cultivated in Dimbokro region and led to large forest surfaces transformed into plantations (Louppe et al., 2013). This forest degradation is a threat for the forest ecosystems and its biodiversity. Therefore, it is necessary to preserve the integrity of the forests of Dimbokro region in the way of local biodiversity conservation.

The effectiveness of this protection could be appreciated through the study of local plant diversity. This study aims at describing the floristic composition of the three main local natural forest types through an assessment of the big and woody trees and lianas. Due to their proximity and the similar anthropogenic activities that are submitted, we hypothesize to find similar richness and diversity in all forest types.

\section{Study zone location}

This study was carried out in the Department of Dimbokro located in Centre-eastern Côte d'Ivoire. Dimbokro (Figure 1) administrative region named N'zi region is limited in the North by Bocanda administrative area, in the South by Tiémélékro administrative area, in the East by Bongouanou administrative area and in the West by Toumodi and Yamoussoukro administrative areas (Zouhou, 2005). Its geographical surface extends between $6^{\circ} 37^{\prime}$ and $6^{\circ} 47^{\prime}$ from Northern latitudes and between $4^{\circ} 38^{\prime}$ and $4^{\circ} 45^{\prime}$ western longitudes and covers $161.9 \mathrm{~km}^{2}$ (Figure 1). The relief is slightly broken with an overall monotony low hills. Local soil is mostly ferralitic while the hydrographic network is composed of N'Zi, Agnéby, Comoé rivers and their tributaries. The vegetation of Dimbokro region belongs to the West African Tropical forest-savanna mosaic (Monnier, 1983; White, 1983) which is a mixt of a semi-deciduous rain forest islands in the Guinean savanna. The local savanna sub-types are the woody savannas, the shrubby savannas and grassy savannas (White, 1983). The local forest sub-types are the forest reserves 
managed by Ivorian forest Service (SODEFOR, 1996), the riparian forests and the forests of plateaus.

\section{Data gathering}

Data were carried out in a total of ninety (90) rectangular plots of 50 $\mathrm{m}$ X $20 \mathrm{~m}$ subdivided each into 10 subplots of $10 \mathrm{~m}$ X $10 \mathrm{~m}$ as recommended Thiombiano et al. (2010) and Kouamé (2016) for the assessment of African Tropical rainforests. Thus, 30 plots in each type of local forest types (reserve, riparian and of plateaus) where sampled for the scientific names of woody plants with diameter at breast height $(\mathrm{DBH})$ equal or larger than $10 \mathrm{~cm}$.

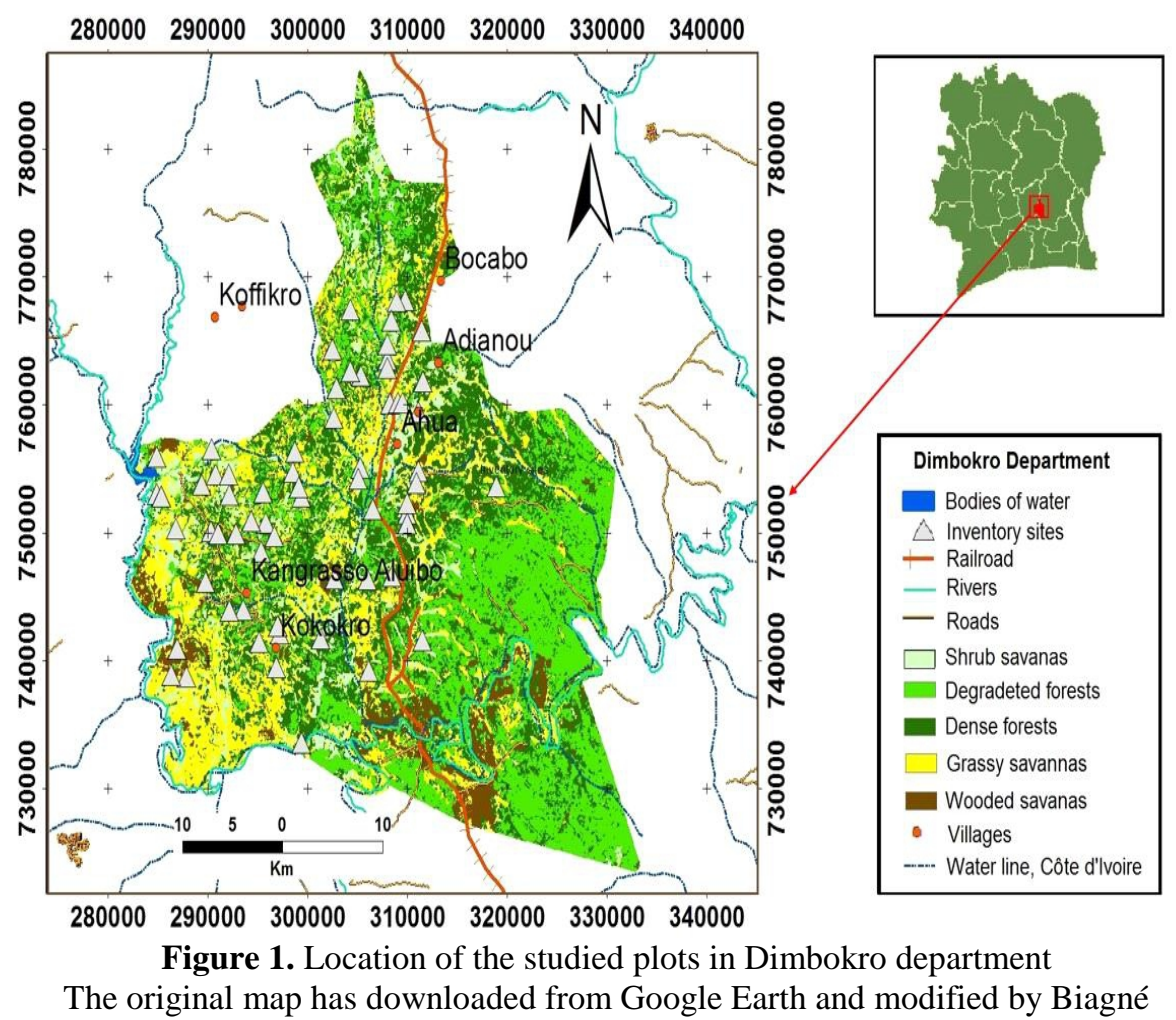

\section{Data analysis}

Botanical analysis consisting of the species and genera names, and the endemism categories were provided by the current checklist of vascular plants of Côte d'Ivoire (Aké-Assi, 2001; 2002). But the nomenclature was updated through APG (2016) for the families' names. The main plant families of the local flora were compared through the genera index which is the average of the species number per genus. The Morisita-Horn's similarity coefficient was use to set the link between the forest types based on their common richness. The floristic diversity was analyzed using various indices such as ShannonWeaner index, Simpson diversity index and Piélou's equitability index. These 
indices and the richness in plots were compared using Kruskal-Wallis nonparametric test. Taxa distribution was analyzed through a Factorial Correspondence Analysis. Statistical tests were performed using $\mathrm{R}$ and XLSTAT software.

\section{Results}

\section{General floristic composition}

The total richness of woody plants with $\mathrm{DBH} \geq 10 \mathrm{~cm}$ assessed in the 90 plots is about 89 species belonging to 77 genera and 32 families (Appendix). The Leguminosae family is the richest (Table 1) with 19 genera (44\%) and 23 species (45\%). The Malvaceae and the Sapindaceae families, with 5 genera $(12 \%)$ and 6 species $(12 \%)$ each represent the second most recorded families (Table 1) followed by the Anacardiaceae family with 4 genera $(9 \%)$ and 5 species $(10 \%)$.

The spectrum of endemic species highlights the abundance of the introduced species (i) with $89 \%$ in the forest reserves, $30 \%$ in the riparian forests and $22 \%$ in the forests of plateaus (Figure 2). The Guineo-Congolian and the Sudano-Zambezian transition endemic species (GCSZ) showed the proportions of $48 \%$ in the forests of plateaus, $44 \%$ in the riparian forests and $5 \%$ in the forest reserves (Figure 2). The Guineo-Congolian endemics (GC) with $27 \%$ in the forests of plateaus, $19 \%$ in the riparian forests and $6 \%$ in the forest reserves are spread as well. The Sudano-Zambezian endemics (SZ) and the Upper Guinea Rainforest Endemics (GCW) are present only in the riparian forests and forests of plateaus in low proportions.

Table 1. The richest woody plants families recorded in the forests of Dimbokro region

\begin{tabular}{|c|l|c|c|c|}
\hline Order & Families & Species & Genera & Genera index \\
\hline 1 & Leguminosae & 23 & 19 & 1.21 \\
2 & Malvaceae & 6 & 5 & 1.20 \\
3 & Sapindaceae & 6 & 5 & 1.20 \\
4 & Anacardiaceae & 5 & 4 & 1.25 \\
5 & Moraceae & 5 & 3 & 1.66 \\
6 & Verbenaceae & 4 & 4 & 1.00 \\
7 & Sapotaceae & 2 & 2 & 1.00 \\
\hline
\end{tabular}




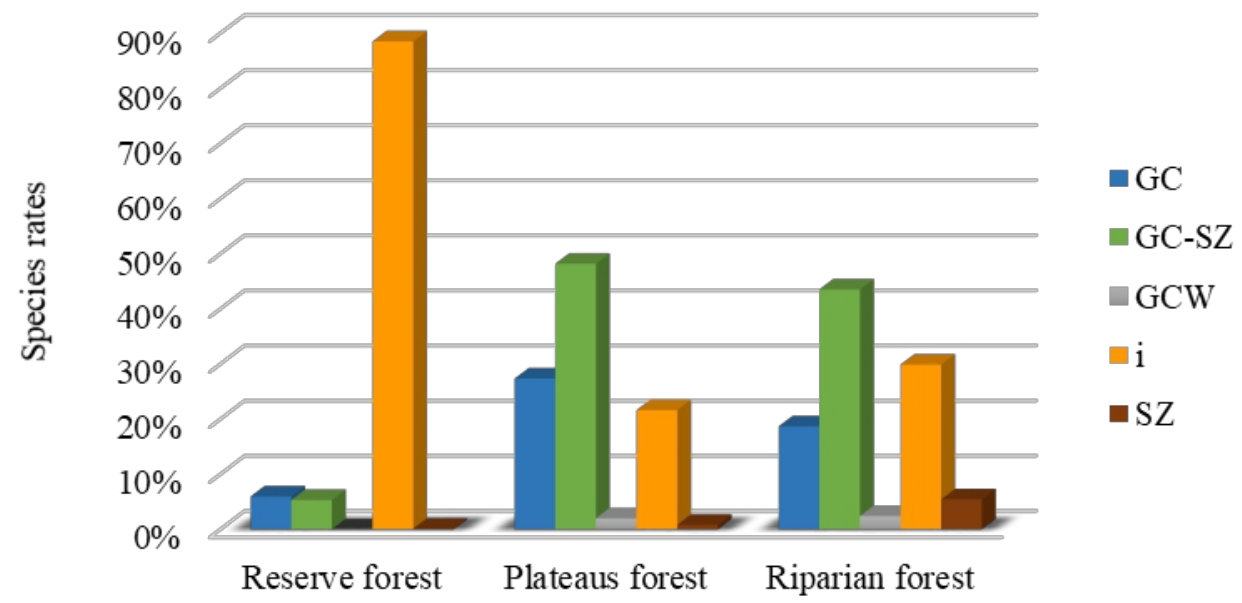

Figure 2. Repartition of the flora of the forest types inside the species endemic groups GC: Guineo-congolian endemics; SZ: Sudano-zambezian endemics; GC-SZ: Guineocongolian and Sudano-zambezian's transition endemics, i: introduced species.

\section{Plot richness}

Analysis of floristic richness by forest type (Tables 2, 3) showed that there were no significant differences in floristic richness between riparian forests and plateaus forests. However, significant differences (F 17.693, $\mathrm{ddl}=2, \mathrm{p}<0.0001$ ) were reported between the forest reserves and the riparian forests and between the forest reserve and the plateaus forests (Tables 2, 3). This number is significantly higher in the forest reserves than in the riparian and plateaus forests (Figure 3).

According to the scale factor of Morisita-Horn, the floristical similarity between the three groups of forests assessed in Dimbokro region is strong because higher than 60\% (Table 4, Appendix). The highest floristical similarity (about $74.2 \%$ ) was observed between the riparian forests and the forests of plateaus while the lowest was observed between the forest reserve and the riparian forests (Table 4, Appendix). Thirty species are common to the three forest groups (Appendix).

\section{Plot diversity}

The riparian forests and the forests of plateaus experienced higher species richness, Shannon-Weaner's diversity index, Simpson's diversity and Pielou's equitability index of woody plants with $\mathrm{DBH} \geq 10 \mathrm{~cm}$ than the forest reserve in Dimbokro Region (Table 2). The riparian forests showed the lowest standard deviation for these parameters (Table 2). For Simpson's index and Pielou's index, the forest reserves experienced higher standard deviation values than the forests of plateaus (Table 2). But for the species richness and Shannon-Weaner's index, the standard deviation values are higher in the 
forests of plateaus in comparison to the forests reserve (Table 2). The difference of richness between the forest reserves and the two other forest groups is very highly (Chi square $=25,618 ; \mathrm{P}<0,0001$ ) significant.

Table 2. Species richness and diversity inside the forest types

\begin{tabular}{|c|l|c|c|c|}
\hline \multirow{2}{*}{} & Parameters & \multicolumn{3}{|c|}{ Types of forest } \\
\cline { 2 - 5 } & Plateaus & Riparian & Reserves \\
\hline \multirow{3}{*}{$\begin{array}{c}\text { Index of } \\
\text { Shannon- } \\
\text { Waener }\end{array}$} & Minimum & 0.210 & 0.657 & 0.000 \\
\cline { 2 - 5 } & Maximum & 2.579 & 2.583 & 1.870 \\
\cline { 2 - 5 } & Mean & $1.601^{\mathrm{a}}$ & $1.723^{\mathrm{a}}$ & $0.832^{\mathrm{b}}$ \\
\cline { 2 - 5 } & Standard deviation & 0.610 & 0.460 & 0.551 \\
\hline \multirow{3}{*}{$\begin{array}{c}\text { Index } \\
\text { of Simpson }\end{array}$} & Minimum & 0.102 & 0.289 & 0.000 \\
\cline { 2 - 5 } & Maximum & 0.906 & 0.916 & 0.783 \\
\cline { 2 - 5 } & Mean & $0.675^{\mathrm{b}}$ & $0.737^{\mathrm{b}}$ & $0.413^{\mathrm{a}}$ \\
\cline { 2 - 5 } & Standard deviation & 0.204 & 0.137 & 0.258 \\
\hline \multirow{3}{*}{$\begin{array}{c}\text { Index of } \\
\text { Piélou }\end{array}$} & Minimum & 0.303 & 0.408 & 0.000 \\
\cline { 2 - 5 } & Maximum & 0.980 & 0.954 & 0.990 \\
\cline { 2 - 5 } & Mean & $0.753^{\mathrm{b}}$ & $0.789^{\mathrm{b}}$ & $0.516^{\mathrm{a}}$ \\
\cline { 2 - 5 } & Standard deviation & 0.178 & 0.124 & 0.285 \\
\hline \multirow{3}{*}{$\begin{array}{c}\text { Species } \\
\text { richness }\end{array}$} & Minimum & 2.000 & 3.000 & 1.000 \\
\cline { 2 - 5 } & Maximum & 17.000 & 15.000 & 12.000 \\
\cline { 2 - 5 } & Mean & $8.833^{\mathrm{b}}$ & $9.200^{\mathrm{b}}$ & $4.867^{\mathrm{a}}$ \\
\cline { 2 - 5 } & Standard deviation & 3.761 & 2.987 & 2.921 \\
\hline \multirow{2}{*}{} & & & \\
\hline
\end{tabular}

Table 3. Comparison of the floristic richness between the couples of forest types according to Tukey's test

Modalities with a 95\% confidence interval

\begin{tabular}{|l|c|c|c|c|c|}
\hline \multicolumn{1}{|c|}{ Contrast } & Difference & $\begin{array}{c}\text { Standardized } \\
\text { difference }\end{array}$ & $\begin{array}{c}\text { Critical } \\
\text { value }\end{array}$ & P & Significant \\
\hline Forest Reserve vs Forest Plateaus & 19.387 & 5.430 & 2.385 & $<0.0001$ & Yes \\
\hline Forest Reserve vs Riparian Forest & 17.000 & 4.802 & 2.385 & $<0.0001$ & Yes \\
\hline Riparian Forest vs Forest Plateaus & 2.387 & 0.669 & 2.385 & 0.782 & No \\
\hline
\end{tabular}

Table 4. Matrix of Morisita-Horn's similarity coefficient

\begin{tabular}{|l|c|c|c|}
\hline & \multicolumn{3}{|c|}{ Types of forest } \\
\hline & Forest reserves & Riparian forest & Plateaus forest \\
\hline Forest reserve & 100 & & \\
\hline Riparian forest & 66.7 & 100 & 100 \\
\hline Plateaus forest & 69.3 & 74.2 & \\
\hline
\end{tabular}




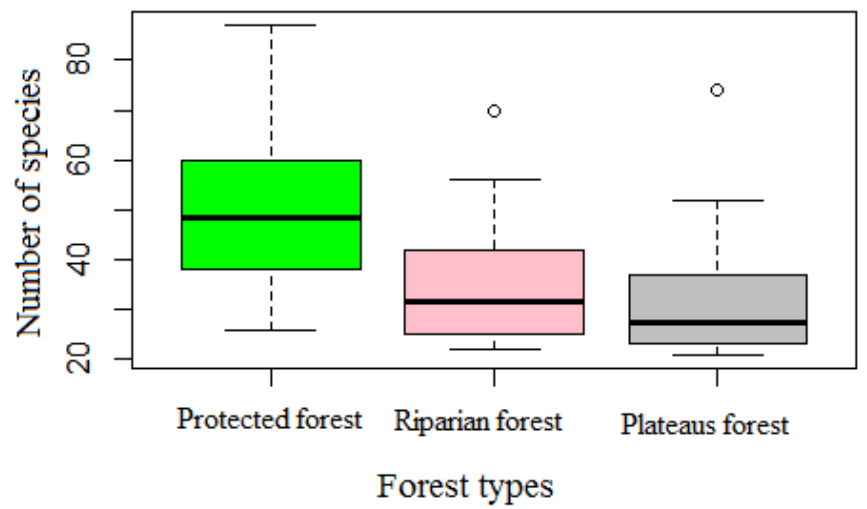

Figure 3. Boxplot of floristic richness in the different study plots according to protected forests, riparian forests and plateaus forests

\section{Species distribution}

The factorial analysis of correspondence of the woody plants with forest types showed two main groups of forest on the axis 2 that represents the forest type (Figure 4) except forest reserve plot 3 (FC 3).

The biggest group with 56 plots is constituted by all the forest of plateaus plots except FP3, FP6, FP13, FP14, FP15, FP28 and FP29, once part, and all the forest reserves plots except FC14, FC16 and FC23, other part (Figure 4). Some riparian forest plots (FG4, FG5, FG8, FG12, FG17, FG22 and FG23) are included in this group. Within this group, woody plant species are separated into an exotic species group gathering Antiaris toxicaria Loes. (Ant-tox), the only one native species which coexists with Anacardium occidentale L. (Ana-occ), Gmelina arborea Roxb. (Gme-arb), Psidium guajava L. (Psi-gua), Senna siamea (Lam.) Irw. \& Barn. (Cas-sia), Tectona grandis L.f. (Tec-gra), and a native species group made of Aidia genipifolia (DC.) Dandy (Aid-gen), Albizia adianthifolia (Schum.) W.F.Wight (Alb-adi), Allophylus africanus P.Beauv. (All-afr) Calycobolus africanus (G.Don) Heine (Cal-afr) that is a liana, Detarium macrocarpum Harms (Det-mic), Distemonanthus benthamianus Baill. (Dis-ben), Terminalia superba Engl. \& Diels (Ter-sup) and Triplochiton scleroxylon K.Schum. (Tri-scl). Between these two groups, there are Glyphaea brevis (Spreng.) Monachino (Gly-bre) and Oxyanthus subpunctatus (Hiern) Keay (Oxy-sub) at a median position (Figure 4).

The second group of 33 plots gathers all the riparian forest plots except FG4, FG5, FG8, FG12, FG17, FG22 and FG23 (Figure 4) and few plots of forest reserves (FC14, FC16 and FC23) and forest of plateaus (FG4, FG5, FG8, FG12, FG17, FG22 and FG23). Within this group, woody plant species are mostly native to savanna or to forest except Azadirachta indica A.Juss. (Aza-ind) which is exotic (Figure 4). The full savanna species are 
Adansonia digitata L. (ada-dig), Borassus aethiopum Mart. (Bor-aet), Bridelia ferruginea Benth. (Bri-fer), Daniellia oliveri (Rolfe) Hutch. \& Dalz. (Dan-oli), Ficus vallis-choudae Del. (Fic-val), Parkia biglobosa (Jacq.) R.Br. ex G.Don (Par-big) and Pterocarpus erinaceus Poir. (Pte-eri) to which can be added the water linked species such as Millettia rhodantha Baill. (Mill-rho) and Pheonix reclinata Jacq. (Pho-rec). The forest species (Figure 4, Appendix) are Albizia adianthifolia W.Wight (Alb-adi), Albizia ferruginea Benth. (Alb-fer), Anthocleista djalonensis A.Chev. (Ant-vog), Aphania senegalensis Radlk. (Aph-sen), Celtis zenkeri Engl. (Cel-zen), Lannea nigritana (Scott Elliot) Keay (Lan-nig) and Mangifera indica L. (Man-ind) to which can be added the water linked species like Carapa procera DC. (Carpro) and Cynometra megalophylla Harms (Cyn-meg), and the forest edge species such as Cola cordifolia Sim (Col-cor) and Pouteria alnifolia (Baker) Robertgy (Pou-aln). These savanna species and forest species (Appendix) are spread on both. 


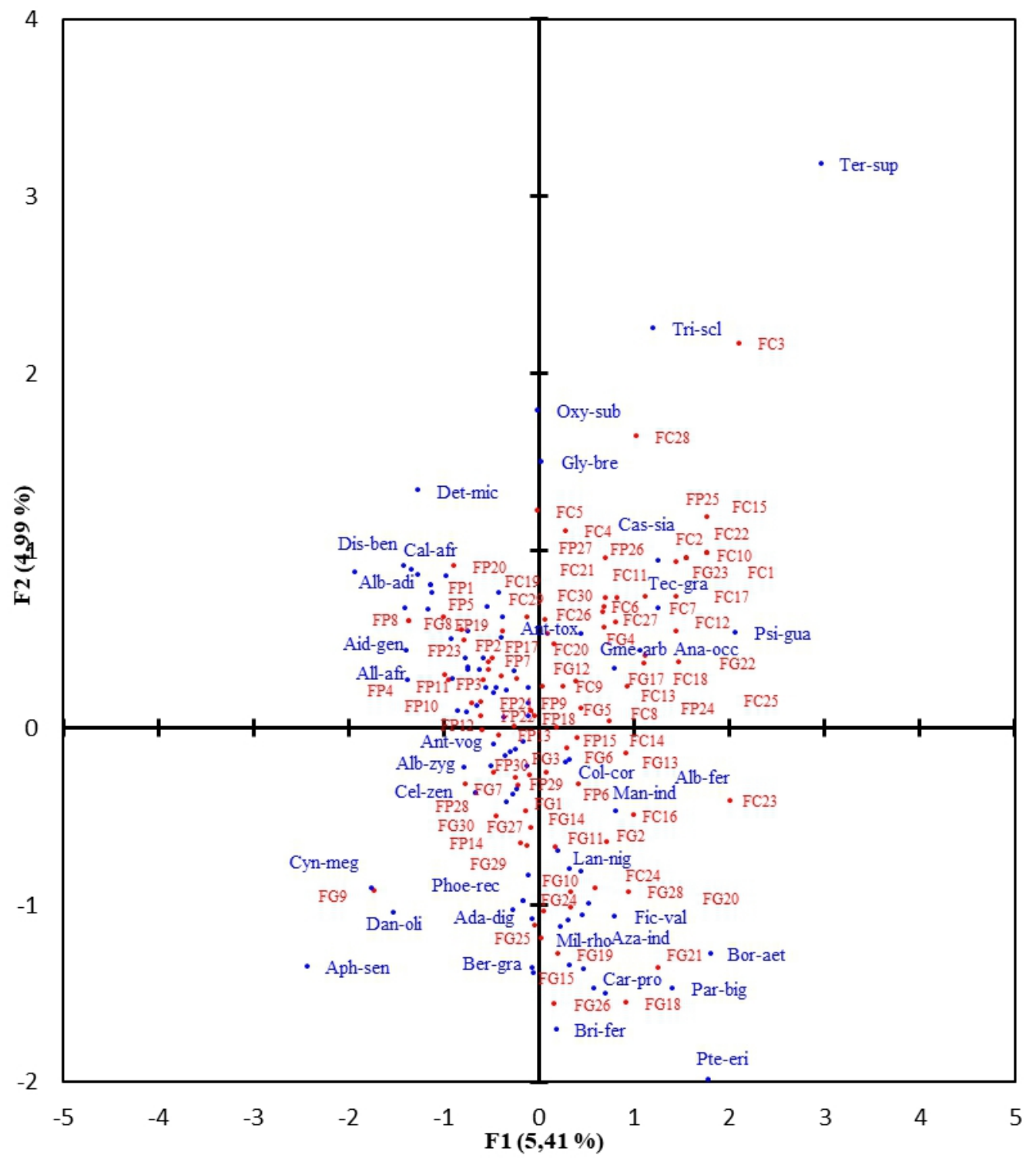

Figure 4. Factorial analysis of correspondence of the woody species and the plots on the two first axes

These first 2 axes absorb $10.40 \%$ of the total inertia with axis 1 that absorbs $5.41 \%$ of the total inertia and represents the openness of the vegetation. Axis 2 that absorbs $4.99 \%$ of the total inertia represents the slope. Read riparian forest for FG, forest reserve for FC and forest of plateaus for FP. 
Woody plant species names (Appendix) are abbreviated using the three first letters of both genus and specific epithet names.

Keay (Lan-nig) and Mangifera indica L. (Man-ind) to which can be added the water linked species like Carapa procera DC. (Car-pro) and Cynometra megalophylla Harms (Cyn-meg), and the forest edge species such as Cola cordifolia Sim (Col-cor) and Pouteria alnifolia (Baker) Robertgy (Pou-aln). These savanna species and forest species (Appendix) are spread on both left and right sides of the axis 2 depending more of the vegetation openness (Figure 4).

The thirty commonest species to three forest groups encompass some natural forest species, some introduced species and some forest edge species (Appendix). These natural forest species are Albizia adianthifolia (Schumach.) W.F.Wright, Albizia ferruginea (Guill. \& Perr.) Benth., Albizia zygia (DC.) J.F.Macbr., Anthonotha macrophylla P.Beauv., Antiaris toxicaria Loes. var. africana C.C.Berg, Baphia pubescens Hook.f., Bersama abyssinica Fresh ssp. paullinioides, Blighia sapida De Koenig, Bombax buenopozense P.Beauv., Ceiba pentandra (L.) Gaerth., Chrysophyllum ubanguiense D.J.Harris, Dialium guineense Willd., Ficus exasperata Vahl, Ficus sur Forsk., Lannea nigritana (Sc.Elliot) Keay, Lecaniodiscus cupanioides Planch., Milicia excelsa (Welw.) Benth., Newbouldia laevis (P.Beauv.) Seem. ex Bureau, Sterculia tragacantha Lindl., Tricalysia macrophylla K.Schum. and Trichilia prieureana A.Juss. ssp. prieureana (Appendix). The introduced species common to the three forest groups are Delonix regia Raf., Gmelina arborea Roxb., Mangifera indica L., Senna siamea (Lam.) Irw. and Tectona grandis L.f. (Appendix). The forest edge species such as Cola cordifolia Sim, Dichrostachys cinerea (L.) Wight \& Arn. and Pouteria alnifolia (Baker) Robertgy are also common to the three forest groups (Appendix).

In terms of the species abundance, Gmelina. arborea Roxb., Senna. siamea (Lam.) Irw. and Tectona. grandis L.f. which are planted for logs showed the highest values of occurrence and individual number inside the plots and the forest groups (Appendix). These taxa experienced each between 15-26 occurrences (50-87\%) and 225-775 individuals (29-50\%) in the forest reserves (Appendix); together they represent $89 \%$ of the individuals in this forest group.

\section{Discussion}

The total number of 89 woody plant species with $\mathrm{DBH} \geq 10 \mathrm{~cm}$ found in the 9 ha plots of this stud) is similar to the 85-89 woody plant species found in a hectare plot of the natural forest of Scio forest Reserve (Nusbaumer et al., 2005; Kouamé et al., 2015; Kouamé, 2016) which is an evergreen rain forest type (Kouamé and Zoro Bi, 2010). But this richness is also slightly higher than the 71-78 woody plant species found in a hectare plot of the natural Haut- 
sassandra forest Reserve (Kouamé, 1998) that is a semi-deciduous forest type (Kouamé and Zoro Bi, 2010). But the natural forest of Dimbokro region which is part of savanna and forest mosaics is almost similar to the semi-deciduous forest in Côte d'Ivoire with the predominance of the families Anacardiaceae, Leguminosae, Malvaceae, Moraceae, Sapindaceae, Sapotaceae, and Verbenaceae, (Table 1) as had shown White (1983) for the African rain semideciduous forest. Indeed, these families dominate the rain semi-deciduous forests of Côte d'Ivoire and of tropical Africa for woody plants with $\mathrm{DBH} \geq 10$ cm (Kouamé, 1998; N’Da et al., 2008, Sonké, 1998).

The weaker richness and diversity of woody plants with $\mathrm{DBH} \geq 10 \mathrm{~cm}$ in forest reserves than the riparian forests and the forests of plateaus of Dimbokro region (Table 2) could be explained by the management technics applied in these forest reserves. In fact, the forest reserves are mostly planted ecosystems made of exotic timber trees like Gmelina. arborea Roxb. or Tectona. grandis L.f. (Appendix). But the maximum richness of 12 species (Table 2) found in these forest reserves shows that some areas of this group forest harbor the natural woody plants in association or not with the above exotic species as had found Kouamé (2016) in Duekoué forest reserve. The vegetation of this forest group undergoes transformations by man inducing the appearance of new plant species that are generally pioneers or weeds and play an important role by increasing local floristic richness (Kouamé, 2016). The highest values of the introduced species in the forest reserves shows how the flora of this forest type is highly transformed by the management activities. Dimbokro region forest reserves are similar to the most forest reserves in Côte d'Ivoire (Ahimin, 2006) that are planted for logs after the cutting of the natural forest vegetation (Sodefor, 1996; Kouamé, 1998). The predominance of the endemic species from the Guineo-congolian and Sudano-zambezian's transition area (GC-SZ) in both the riparian forests and the forests of plateaus confirms the status of the forest and savanna mosaic always attributed to natural vegetation of Dimbokro region (Monnier, 1983; White, 1983; Chatelain et al., 2004). According to Sinsin (1993), such vegetation shows a high proportion of the broad distribution area species.

The anthropogenic activities including annual bush fire and persistent agriculture in both riparian forests and forests of plateaus induce some exotic introduced species in these areas (Appendix) as had found Asia et al. (2008) and Akoègninou (2004). Depending on the intensity of the bush fires related to the annual drought and the quantity of the vegetation burn these forest groups can have a drastic decrease in plant richness (Sangne et al., 2008). But these two forest groups harbor higher richness, diversity and equitability of woody plants with $\mathrm{DBH} \geq 10 \mathrm{~cm}$ than the forest reserves in Dimbokro region (Table 2). That suggests the lower impacts of both bush fire and local 
agriculture on the woody plant richness and distribution in comparison to those of the management process in the forest reserves.

The values of the diversity indices obtained within the 3 types of forest of Dimbokro region (Table 2) are lower than those found in several areas in Côte d'Ivoire. Indeed, the maximum diversity index value of Dimbokro region forest is lower than the minimum value of this index in Scio forest reserve natural vegetation (Kouamé et al., 2015; Kouamé, 2016) and other forests of Western Côte d'Ivoire (Bakayoko, 2005). But Dimbokro region forest types experienced higher Shannon-Weaner index values than the coffee and cocoa farms in the Duekoué and Scio forest reserves (Kouamé et al., 2015; Kouamé, 2016). These results could be explained by the extensive exploitation of woods by the forest owners and the rural populations in the study area. Group of woody plant species are usually cut or burnt for agricultural, social, economic and cultural purposes by local populations. Additionally, the local annual drought and bush fire are extremely severe due to the high temperature in the region (Eldin et al., 1979) and led to a selection of woody plant species that can survive in such conditions. Amongst these naturally selected woody plants there are 9 species with particular status according the red list of the UICN (2015) and 2 species on the list of Aké-Assi (1988). That gives a particular interest of conservation to Dimbokro region forests as had suggested Myers et $a l$. (2000) that efforts of conservation of endemic species, rare species and threatened species of extinction must be a priority.

The two groups of forests shown by the factorial analysis of correspondence rather than three groups (riparian, plateaus and reserve) considered in this study illustrate that the forests in Dimbokro region depend only on the slope and the vegetation openness. Most of riparian forests are along the streams in the valleys with a low slope and meandering in the savanna area. Therefore, their flora is a combination of savanna species able to live in conditions of water saturated soil and of medium shade tolerance, and of forest species able to survive to the local annual drought and bush fire as had shown Spichiger and Pamard (1973), Spichiger (1977) and Devineau (1984) in Lamto region. Due to their short width, they are not explicitly subject of introduction of exotic woody plants like Gmelina. arborea Roxb., Senna. siamea (Lam.) Irw. \& Barn. and Tectona. grandis L.f. The presence of these species within some riparian forests could be explained by the plant natural distribution agents like the wind, the animals and the water's flux that bring their seeds in the milieu. Both forest reserves and of plateaus are at the high slopes harbor the exotic species introduced during the forest management activities and the semi-deciduous forest natural species as demonstrated Adjonou et al. (2010). Finally, the forests of plateaus have a medium position amongst the three forest groups studied in Dimbokro region. In terms of 
richness and diversity, they are similar to the riparian forests while in terms of species spatial distribution, they are rather closed to the forest reserves.

\section{Conclusion}

The flora of woody plants with $\mathrm{DBH} \geq 10 \mathrm{~cm}$ assessed in the 90 plots of $1000 \mathrm{~m}^{2}$ in Dimbokro region forest types showed 89 species 77 genera and 32 families among which the main are families Leguminosae, Malvaceae, Sapindaceae, Anacardiaceae, Moraceae and Verbenaceae. Despite their lower richness in comparison to other rainforests in Côte d'Ivoire, Dimbokro region forests harbor at least 11 species with particular status consisting of 9 species on the red list of UICN and 2 species on the list of Aké-Assi. The forests of plateaus and the riparian forests harbor the same richness about 9 species of woody plants with $\mathrm{DBH} \geq 10 \mathrm{~cm}$ per plot of $1000 \mathrm{~m}^{2}$ dominated by the Guineo-congolian and the Sudano-zambezian transition endemic species. Both forest types experienced similar diversity and equitability but are different in terms of the species spatial distribution driven by the slope height and the vegetation openness. The forest reserves were poorer with 5 species plot of $1000 \mathrm{~m}^{2}$ and showed lower diversity and equitability; their flora was mostly reduced to the planted species by the forest service to which few remaining natural species were sometime associated. The height of the slope and the vegetation openness of these forest reserves led to similar spatial distribution of the woody plants with $\mathrm{DBH} \geq 10 \mathrm{~cm}$ as the forests of plateaus. Finally, our hypothesis to have similar richness and diversity in overall forests of Dimbokro due to short distance between them and the similar anthropogenic activities that they are submitted is rejected.

\section{References:}

1. Adjonou, K., Djiwa, O., Kombate, Y., Kokutse, A. D. \& Kokou, K. (2010). Etude de la dynamique spatiale et structure des forêts denses sèches reliques du Togo: implications pour une gestion durable des protégées. Int. J. Biol. Chem. Sci. 4(1), 168-183.

2. Ahimin, A. O. (2006). Détermination des aires abritant les formations végétales à haute valeur de conservation identifiées dans le Domaine guinéen de la Côte d'Ivoire. Mémoire DEA, UFR Biosciences, Université de Cocody-Abidjan (71 p).

3. Aké-Assi, L. (1984). Flore de la Côte d'Ivoire : étude descriptive et biogéographique, avec quelques notes ethnobotaniques. Thèse Doctorat, Université Nationale d'Abidjan, Côte d'Ivoire (1206 p).

4. Aké-Assi, L. (1988). Espèces rares et en voie d'extinction de la flore de la Côte d'Ivoire. Monogr. Syst. Bot. Missouri Bot.Gard. 25, 461463. 
5. Aké-Assi, L. (2001). Flore de la Côte d'Ivoire 1, catalogue, systématique, biogéographie et écologie, Conservatoire et Jardin Botanique de Genève. Genève, Suisse, Boisseria 57 (396 p).

6. Aké-Assi, L. (2002). Flore de la Côte d'Ivoire 2, catalogue, systématique, biogéographie et écologie. Conservatoire et Jardin Botanique de Genève. Genève, Suisse, Boisseria 58 (441 p).

7. Akoègninou, A. (2004). Recherches botaniques et écologiques sur les forêts actuelles du Bénin. Thèse d'État, Université de CocodyAbidjan, Côte d'Ivoire (326 p).

8. APG (2016). An update of the Angiosperm Phylogeny Group classification for the orders and families of flowering plants: APG IV. Botanical Journal of the Linnean Society 181, 1-20.

9. Assié, K. H., Angui, K. T. P. \& Tamia A. J. (2008). Effets de la mise en culture et des contraintes naturelles sur quelques propriétés physiques d'un sol ferralitique au Centre Ouest de la Côte d'Ivoire: conséquences sur la dégradation des sols. European Journal of Scientific Research, 23 (1), 149-166.

10. Chatelain, C., Dao H., Gautier, L. \& Spichiger, R. E. (2004). Forest cover changes in Côte d'Ivoire and Upper Guinea. In: Poorter, L., Bongers, F., Kouamé, F. N. \& Hawthorne, W. D. (eds). Biodiversity of West African forests. An ecological Atlas of woody plant species. CABI Publishing, UK (pp. 15-32).

11. Devineau, J. L. (1984). Structure et dynamique de quelques forêts tropophiles de l'Ouest africain (Côte d'Ivoire). Thèse de Doctorat d'Etat, Université de Paris VI (294 p).

12. Eldin, M., Combres, J. C. \& Montels, J. (1979). Éléments généraux du climat. A3a. Précipitations mensuelles. A3b. Déficits hydriques Durée de la saison sèche. A3c. In : Anonyme (eds). Atlas de Côte d'Ivoire. Minist. Plan de Côte d'Ivoire/IGT-Université d'Abidjan/ ORSTOM (72 p).

13. FAO (2015). Comment les forêts de la planète changent-elles ? Deuxième édition. http://www.fao.org (46 p).

14. Heithecker, T. D. \& Halpern, C. B. (2007). Edge-related gradients in microclimate in forest aggregates following structural retention harvests in western Washington. For. Ecol. Manage., 248(3), 163-173.

15. Kokou, K., Adjossou, K. \& Hamberger, K. (2005). Les forêts sacrées de l'aire Ouatchi au sud-est du Togo et les contraintes actuelles des modes de gestion locale des ressources forestières. http://vertigo.revues.org/2456.

16. Kouamé, N. F. (1998). Influence de l'exploitation forestière sur la végétation et la flore de la forêt classée du Haut Sassandra (Centre- 
Ouest de la Côte d'Ivoire). Thèse Doct. 3e cycle, UFR Biosc., Université de. Cocody-Abidjan, Côte d'Ivoire (227 p).

17. Kouamé, N. F. (2016). Structure de la végétation, flore et régénération des forêts classées de Duékoué et de Scio dans la zone de forêt dense humide de l'ouest de la Côte d'Ivoire. Thèse Unique, Université Félix Houphouët-Boigny, Côte d'Ivoire (285 p).

18. Kouamé, N. F., Ahimin, A. O., Boraud, N. K. M. \& N'guessan, K. E. (2015). Floristic diversity under anthropogenic activities in the protected forests of Duekoué and Scio in southwestern Côte d'Ivoire. African Journal of Plant Science 9(3), 128-146.

19. Kouamé, N. F., Tra Bi, F. H., Etien, D. \& Traoré, D. (1998). Végétation et flore de la forêt classée du Haut-Sassandra en Côte d'Ivoire. Revue du Cames, Science et Médecine 00, 28-35.

20. Laurance, W. F. \& Curran, T. J. (2008). Impacts of wind disturbance on fragmented tropical forests: a review and synthesis. Austral Ecol. 33(4), 399-408.

21. Louppe, D. \& Ouattara, N. K. (2013). Etude sur l'exploitation forestière et les contraintes d'une gestion durable des forêts dans le domaine rural en Côte d'Ivoire. DOI : 10.13140/ RG.2.1.5017.3047 (68 p).

22. Monnier, Y (1983). Carte de la végétation de la Côte d'Ivoire. In : Vennetier, P. \& Laclavère, G. (eds) : Atlas de Côte d'Ivoire. 2e éd., Jeune Afrique, Paris (72 p).

23. Myers, N., Mittermeier, R. A., Mittermeier, C. G., Da Fonseca, G. A. B. \& Kent, J. (2000). Biodiversity hotspots for conservation priorities. Nature 403, 853-858.

24. N'Da, D. H., Adou Yao, C. Y., N'Guessan, K. E., Koné, M. \& Sangne, Y. C. (2008). Analyse de la diversité floristique du Parc National de la Marahoué, Centre-ouest de la Côte d'Ivoire. Afrique Science 4(3), 552579.

25. Nusbaumer, L., Gautier, L., Chatelain, C. \& Spichiger, R. E. (2005). Structure et composition floristique de la forêt classée de la Scio (Côte d'Ivoire). Etude descriptive et comparative. Candollea 60(2), 393-443.

26. Païvinen. R., Pitkanen, J. \& Witt, R. (1992). Mapping closed forest cover in West Africa, using NOAA/AVHRR-LAC data. Silva Carelica 21, 27-51.

27. Sangne, Y. C., Adou Yao, C. Y. \& N'Guessan, K. E. (2008). Transformations de la flore d'une forêt dense Semi-décidue : impact des activités humaines (Centre Ouest de la Côte d'Ivoire). Agronomie Africaine 20 (1), 1-11. 
28. Sinsin, B. (1993). Phytosociologie, écologie, valeur pastorale, production et capacité de charge naturelle du périmètre Nikki-Kalalé. Thèse de Doctorat unique, Université Libre de Bruxelles (390 p).

29. SODEFOR (1996). Plan d'aménagement de la forêt classée de Bouaflé. Abidjan, $61 \mathrm{p}$.

30. Sonké, B. (1998). Etudes floristiques et structurales des forêts de la réserve de faune du Dja (Cameroun). Thèse de Doctorat, Université Libre Bruxelles (267 p).

31. Spichiger, R. E. (1977). Contribution à l'étude du contact entre flores sèche et humide sur les lisières des formations forestières humides semi-décidues du V-Baoulé et de son extension nord-ouest (Côte d'Ivoire Centrale). Thèse Doct. ès-Sc., Fac. Sc., Université de Genève (261 p).

32. Spichiger, R. E. \& Pamard, C. (1973). Recherches sur le contact forêtsavane en Côte d'Ivoire : du recru forestier dans le Sud du pays Baoulé. Candollea 28, 21-37.

33. Thiombiano, A., Hahn-Hadjali, K., Koulibaly, A. \& Sinsin, B. (2010). Collecte des données sur les plantes. In : Konate, S. \& Kampmann, D. (eds). Atlas de la biodiversité de l'Afrique de l'Ouest. Vol. III. Côte d'Ivoire. Biota, Abidjan \& Frankfurt/Main (pp. 444-478).

34. Trochain, J. L. (1980). Écologie végétale de la zone intertropicale non désertique. Publications Université Paul Sabatier, Toulouse (458 p).

35. UICN (2015). Red list of threatened species. Version 2015. 2. www.iucnredlist.org.

36. Vroh, B. T. A., Adou Yao, C. Y., Kouamé, D., N’Da, D. H. \& N'Guessan, K. E. (2010). Diversités Floristique et Structurale sur le Site d'une Réserve Naturelle Volontaire à Azaguié, Sud-est de la Côte d'Ivoire. European Journal of Scientific Research 45 (3), 411-421.

37. White, F. (1983). The vegetation of Africa, a descriptive memoir to accompany the UNESCO/AET-FAT/UNSO vegetation map of Africa. Natural resources research XXIV, UNESCO, Paris (384 p).

38. Zouhou, G. R. P. (2005). Ville et village de Côte d'Ivoire. RezoIvoire.net| La référence culturelle de la Côte d'Ivoire (6 p). 


\section{Appendix}

Occurrences and individual number of the woody plant species in the forest types of Dimbokro region

\begin{tabular}{|c|c|c|c|c|c|c|c|}
\hline & Forest types & \multicolumn{2}{|c|}{ Forest reserves } & \multicolumn{2}{|c|}{ Riparian forests } & \multicolumn{2}{|c|}{ Forests of plateaus } \\
\hline $\mathrm{N}^{\circ}$ & Species & Occurrence & \begin{tabular}{|c|}
$\begin{array}{c}\text { Individual } \\
\text { number }\end{array}$ \\
\end{tabular} & Occurrence & $\begin{array}{c}\text { Individual } \\
\text { number }\end{array}$ & Occurrence & $\begin{array}{c}\text { Individual } \\
\text { number }\end{array}$ \\
\hline 1 & $\begin{array}{l}\text { Adansonia } \\
\text { digitata } \mathrm{L} .\end{array}$ & & & & & 1 & 1 \\
\hline 2 & $\begin{array}{l}\text { Aidia genipiflora } \\
\text { (DC.) Dandy }\end{array}$ & & & 4 & 7 & 7 & 22 \\
\hline 3 & $\begin{array}{l}\text { Albizia } \\
\text { adianthifolia } \\
\text { (Schumach.) } \\
\text { W.F.Wright }\end{array}$ & 2 & 6 & 3 & 5 & 11 & 31 \\
\hline 4 & $\begin{array}{l}\text { Albizia ferruginea } \\
\text { (Guill. \& Perr.) } \\
\text { Benth. }\end{array}$ & 5 & 19 & 8 & 27 & 5 & 25 \\
\hline 5 & $\begin{array}{l}\text { Albizia zygia } \\
\text { (DC.) J.F.Macbr. }\end{array}$ & 1 & 1 & 8 & 12 & 15 & 54 \\
\hline 6 & $\begin{array}{l}\text { Allophylus } \\
\text { africanus } \\
\text { P.Beauv. }\end{array}$ & & & & & 2 & 2 \\
\hline 7 & $\begin{array}{l}\text { Alstonia boonei } \\
\text { De Wild. }\end{array}$ & 1 & 9 & 1 & 2 & 3 & 5 \\
\hline 8 & $\begin{array}{l}\text { Anacardium } \\
\text { occidentalis } \mathrm{L} \text {. }\end{array}$ & & & 2 & 3 & & \\
\hline 9 & $\begin{array}{l}\text { Anthocleista } \\
\text { vogelii Planch. }\end{array}$ & & & 1 & 4 & 3 & 6 \\
\hline 10 & $\begin{array}{l}\text { Anthonotha } \\
\text { macrophylla } \\
\text { P.Beauv. }\end{array}$ & 2 & 3 & 5 & 37 & 4 & 18 \\
\hline 11 & $\begin{array}{l}\text { Antiaris toxicaria } \\
\text { Loes. var. } \\
\text { africana } \text { C.C.Berg }\end{array}$ & 6 & 8 & 2 & 2 & 9 & 19 \\
\hline 12 & $\begin{array}{l}\text { Aphania } \\
\text { senegalensis } \\
\text { (Juss. ex Poir.) } \\
\text { Radlk. }\end{array}$ & & & 1 & 1 & & \\
\hline 13 & $\begin{array}{l}\text { Aubrevillea } \\
\text { kerstingii (Harms) } \\
\text { Pellegr. }\end{array}$ & & & 1 & 3 & 1 & 3 \\
\hline 14 & $\begin{array}{l}\text { Azadirachta } \\
\text { indica A. Juss. }\end{array}$ & & & 5 & 17 & & \\
\hline 15 & $\begin{array}{l}\text { Baphia pubescens } \\
\text { Hook.f. }\end{array}$ & 3 & 13 & 5 & 21 & 8 & 26 \\
\hline 16 & $\begin{array}{l}\text { Berlinia } \\
\text { grandiflora (Vahl) } \\
\text { Hutch. \& DaIz. }\end{array}$ & & & 7 & 22 & & \\
\hline 17 & $\begin{array}{l}\text { Berlinia } \\
\text { occidentalis Keay }\end{array}$ & & & 2 & 7 & 4 & 5 \\
\hline 18 & $\begin{array}{l}\text { Bersama } \\
\text { abyssinica } \text { Fresh } \\
\text { ssp. paullinioides }\end{array}$ & 1 & 1 & 3 & 3 & & \\
\hline
\end{tabular}




\begin{tabular}{|c|c|c|c|c|c|c|c|}
\hline 19 & $\begin{array}{l}\text { Blighia sapida De } \\
\text { Koenig }\end{array}$ & 1 & 1 & 2 & 5 & 11 & 15 \\
\hline 20 & $\begin{array}{l}\text { Blighia unijugata } \\
\text { Baker }\end{array}$ & & & & & 3 & 4 \\
\hline 21 & $\begin{array}{l}\text { Bombax } \\
\text { buenopozense } \\
\text { P.Beauv. } \\
\end{array}$ & 4 & 4 & 4 & 6 & 10 & 17 \\
\hline 22 & $\begin{array}{l}\text { Borassus } \\
\text { aethiopum Mart. }\end{array}$ & 1 & 3 & 3 & 3 & & \\
\hline 23 & $\begin{array}{l}\text { Bridelia } \\
\text { ferruginea } \text { Benth. }\end{array}$ & & & 4 & 5 & & \\
\hline 24 & \begin{tabular}{|l|} 
Calycobolus \\
africanus (G.Don) \\
Heine
\end{tabular} & 1 & 1 & & & 1 & 1 \\
\hline 25 & $\begin{array}{l}\text { Carapa procera } \\
\text { (DC.) De Wilde }\end{array}$ & & & 1 & 12 & & \\
\hline 26 & $\begin{array}{l}\text { Ceiba pentandra } \\
\text { (L.) Gaerth. }\end{array}$ & 4 & 10 & 7 & 12 & 13 & 43 \\
\hline 27 & $\begin{array}{l}\text { Celtis zenkeri } \\
\text { EngI. }\end{array}$ & & & 1 & 1 & 4 & 6 \\
\hline 28 & \begin{tabular}{|l|} 
Chaetacme \\
aristata E.Mey. ex \\
Planch.
\end{tabular} & & & 1 & 6 & & \\
\hline 29 & $\begin{array}{l}\text { Christiana } \\
\text { afrïcana } \mathrm{DC} .\end{array}$ & & & & & 1 & 2 \\
\hline 30 & $\begin{array}{l}\text { Chrysophyllum } \\
\text { ubanguiense } \\
\text { D.J.Harris } \\
\end{array}$ & 1 & 1 & 1 & 1 & 1 & 1 \\
\hline 31 & $\begin{array}{l}\text { Cola caricaefolia } \\
\text { (G. Don) } \\
\text { K.Schum. } \\
\end{array}$ & & & & & 2 & 2 \\
\hline 32 & $\begin{array}{l}\text { Cola cordifolia } \\
\text { (Cav.) R.Br. }\end{array}$ & 5 & 9 & 8 & 49 & 6 & 19 \\
\hline 33 & \begin{tabular}{|l|} 
Croton aubrevillei \\
J.Léanard
\end{tabular} & & & & & 1 & 1 \\
\hline 34 & \begin{tabular}{|l|} 
Cussonia arborea \\
Hochst. ex \\
A.Rich. \\
\end{tabular} & & & & & 1 & 1 \\
\hline 35 & \begin{tabular}{|l|} 
Cynometra \\
megalophylla \\
Harms \\
\end{tabular} & & & 2 & 13 & & \\
\hline 36 & $\begin{array}{l}\text { Dalbergia } \\
\text { oblongifolia } \\
\text { G.Don } \\
\end{array}$ & & & & & 1 & 1 \\
\hline 37 & $\begin{array}{l}\text { Daniellia oliveri } \\
\text { Hutch. \& Dalz. }\end{array}$ & & & 2 & 16 & & \\
\hline 38 & Delonix regia Raf. & 1 & 4 & 2 & 15 & 3 & 84 \\
\hline 39 & $\begin{array}{l}\text { Dennettia } \\
\text { tripetala Bak.f. }\end{array}$ & & & & & 1 & 2 \\
\hline 40 & \begin{tabular}{|l} 
Detarium \\
microcarpum \\
Guill. \& Perr. \\
\end{tabular} & & & & & 1 & 1 \\
\hline 41 & $\begin{array}{l}\text { Dialium guineense } \\
\text { Willd. }\end{array}$ & 4 & 12 & 7 & 27 & 11 & 29 \\
\hline
\end{tabular}




\begin{tabular}{|c|c|c|c|c|c|c|c|}
\hline 42 & $\begin{array}{l}\text { Dichapetalum } \\
\text { crassifolium } \\
\text { Chodat }\end{array}$ & & & & & 1 & 1 \\
\hline 43 & $\begin{array}{l}\text { Dichrostachys } \\
\text { cinerea (L.) Wight } \\
\text { \& Arn. }\end{array}$ & 1 & 2 & 1 & 1 & 3 & 5 \\
\hline 44 & $\begin{array}{l}\text { Distemonanthus } \\
\text { benthamianus } \\
\text { Baill. }\end{array}$ & & & 1 & 1 & 1 & 1 \\
\hline 45 & $\begin{array}{l}\text { Dracaena mannii } \\
\text { Baker }\end{array}$ & & & & & 3 & 8 \\
\hline 46 & $\begin{array}{l}\text { Erythrophleum } \\
\text { suaveolens } \text { Brenan }\end{array}$ & & & 2 & 3 & 2 & 6 \\
\hline 47 & $\begin{array}{l}\text { Ficus exasperata } \\
\text { Vahl }\end{array}$ & 2 & 2 & 6 & 8 & 3 & 5 \\
\hline 48 & Ficus sur Forsk. & 3 & 6 & 13 & 98 & 1 & 1 \\
\hline 49 & $\begin{array}{l}\text { Ficus vallis- } \\
\text { choudae Del. }\end{array}$ & & & 2 & 4 & 1 & 1 \\
\hline 50 & $\begin{array}{l}\text { Glyphaea brevis } \\
\text { (Spreng.) } \\
\text { Monachino }\end{array}$ & 3 & 4 & & & 1 & 1 \\
\hline 51 & $\begin{array}{l}\text { Gmelina arborea } \\
\text { Roxb. }\end{array}$ & 20 & 375 & 14 & 122 & 12 & 99 \\
\hline 52 & $\begin{array}{l}\text { Harrisonia } \\
\text { abyssinica Oliv. }\end{array}$ & & & & & 1 & 3 \\
\hline 53 & $\begin{array}{l}\text { Holarrhena } \\
\text { floribunda } \\
\text { (G.Don) Dur. \& } \\
\text { Schinz } \\
\end{array}$ & & & 10 & 16 & 7 & 12 \\
\hline 54 & $\begin{array}{l}\text { Lannea barteri } \\
\text { (Oliv.) Engl. }\end{array}$ & & & 9 & 14 & 2 & 2 \\
\hline 55 & $\begin{array}{l}\text { Lannea nigritana } \\
\text { (Sc.Elliot) Keay }\end{array}$ & 1 & 2 & 1 & 3 & & \\
\hline 56 & $\begin{array}{l}\text { Lecaniodiscus } \\
\text { cupanioides } \\
\text { Planch. }\end{array}$ & 5 & 8 & 2 & 7 & 7 & 16 \\
\hline 57 & $\begin{array}{l}\text { Mangifera indica } \\
\text { L. }\end{array}$ & 3 & 6 & 3 & 12 & 1 & 1 \\
\hline 58 & $\begin{array}{l}\text { Margaritaria } \\
\text { discoidea (Baill.) } \\
\text { Webster } \\
\end{array}$ & & & 6 & 18 & 1 & 1 \\
\hline 59 & $\begin{array}{l}\text { Milicia excelsa } \\
\text { (Welw.) Benth. }\end{array}$ & 2 & 2 & 2 & 3 & 2 & 2 \\
\hline 60 & $\begin{array}{l}\text { Millettia } \\
\text { rhodontha } \text { Baill. }\end{array}$ & & & 7 & 18 & 3 & 10 \\
\hline 61 & $\begin{array}{l}\text { Millettia zechiana } \\
\text { Harms }\end{array}$ & & & 2 & 2 & 1 & 8 \\
\hline 62 & $\begin{array}{l}\text { Newbouldia laevis } \\
\text { (P.Beauv.) Seem. } \\
\text { ex Bureau }\end{array}$ & 1 & 1 & 2 & 2 & 2 & 3 \\
\hline 63 & $\begin{array}{l}\text { Ochthocosmus } \\
\text { africanus Hook.f. }\end{array}$ & & & & & 2 & 13 \\
\hline 64 & $\begin{array}{l}\text { Olax } \\
\text { subscorpioidea } \\
\text { Oliv. }\end{array}$ & & & 2 & 2 & 1 & 3 \\
\hline
\end{tabular}




\begin{tabular}{|c|c|c|c|c|c|c|c|}
\hline 65 & $\begin{array}{l}\text { Oxyanthus } \\
\text { subpunctatus } \\
\text { (Hiern.) Keay }\end{array}$ & 1 & 1 & & & & \\
\hline 66 & $\begin{array}{l}\text { Parkia biglobosa } \\
\text { (Jacq.) Benth. }\end{array}$ & 1 & 1 & 2 & 3 & & \\
\hline 67 & $\begin{array}{l}\text { Phoenix reclinata } \\
\text { Jacq. }\end{array}$ & & & 5 & 15 & 1 & 1 \\
\hline 68 & $\begin{array}{l}\text { Piliostigma } \\
\text { thonningii Millne- } \\
\text { Redhead }\end{array}$ & & & 6 & 18 & & \\
\hline 69 & $\begin{array}{l}\text { Pouteria alnifolia } \\
\text { (Bak.) Roberty }\end{array}$ & 3 & 4 & 10 & 54 & 13 & 131 \\
\hline 70 & $\begin{array}{l}\text { Psidium guajava } \\
\text { L. }\end{array}$ & & & 1 & 1 & & \\
\hline 71 & $\begin{array}{l}\text { Pterocarpus } \\
\text { erinaceus Poilr. }\end{array}$ & & & 1 & 1 & & \\
\hline 72 & $\begin{array}{l}\text { Ricinodendron } \\
\text { heudelotii (Baill.) } \\
\text { Pierre ex Pax }\end{array}$ & 1 & 1 & & & 4 & 14 \\
\hline 73 & $\begin{array}{l}\text { Rothmannia } \\
\text { hispida } \\
\text { (K.Schum.) } \\
\text { Fagerl. } \\
\end{array}$ & 1 & 1 & 2 & 2 & & \\
\hline 74 & $\begin{array}{l}\text { Sarcocephalus } \\
\text { latifolius (Smith) } \\
\text { Bruce }\end{array}$ & & & 4 & 4 & & \\
\hline 75 & $\begin{array}{l}\text { Scottellia } \\
\text { klaineana } \text { Pierre }\end{array}$ & & & & & 2 & 2 \\
\hline 76 & $\begin{array}{l}\text { Senna siamea } \\
\text { (Lam.) Irw. }\end{array}$ & 15 & 225 & 8 & 90 & 5 & 81 \\
\hline 77 & $\begin{array}{l}\text { Smeathmannia } \\
\text { pubescens Soland } \\
\text { ex R.Br. }\end{array}$ & & & 2 & 3 & 1 & 1 \\
\hline 78 & $\begin{array}{l}\text { Spondias mombin } \\
\text { L. }\end{array}$ & 3 & 4 & 7 & 10 & 10 & 18 \\
\hline 79 & $\begin{array}{l}\text { Sterculia } \\
\text { tragacantha } \\
\text { Lindl. }\end{array}$ & 2 & 2 & 6 & 28 & 5 & 9 \\
\hline 80 & $\begin{array}{l}\text { Tectona grandis } \\
\text { L.f. }\end{array}$ & 26 & 775 & 11 & 79 & 2 & 28 \\
\hline 81 & $\begin{array}{l}\text { Terminalia } \\
\text { schimperi Hochst. }\end{array}$ & 1 & 1 & 9 & 33 & 3 & 5 \\
\hline 82 & $\begin{array}{l}\text { Terminalia } \\
\text { superba Engl. \& } \\
\text { Diels }\end{array}$ & 1 & 2 & & & & \\
\hline 83 & $\begin{array}{l}\text { Tricalysia } \\
\text { macrophylla } \\
\text { K.Schum }\end{array}$ & 2 & 5 & 5 & 11 & 6 & 9 \\
\hline 84 & $\begin{array}{l}\text { Tricalysia reflexa } \\
\text { Hutch. var. reflexa }\end{array}$ & & & & & 1 & 1 \\
\hline 85 & $\begin{array}{l}\text { Trichilia } \\
\text { prieureana } \\
\text { A.Juss. subsp. } \\
\text { prieureana }\end{array}$ & 2 & 3 & 2 & 3 & 5 & 7 \\
\hline
\end{tabular}




\begin{tabular}{|c|c|c|c|c|c|c|c|}
\hline 86 & \begin{tabular}{|l} 
Triplochiton \\
scleroxylon \\
K.Schum. \\
\end{tabular} & 4 & 15 & & & & \\
\hline 87 & $\begin{array}{l}\text { Vitex doniana } \\
\text { Sweet }\end{array}$ & & & 6 & 10 & 1 & 1 \\
\hline 88 & \begin{tabular}{|l|} 
Warneckea \\
membranifolia \\
(Hook.f.) Jac.-Fél.
\end{tabular} & & & & & 1 & 4 \\
\hline \multirow[t]{2}{*}{89} & \begin{tabular}{|l|} 
Zanthoxylum \\
leprieurii Guill. \& \\
Perr.
\end{tabular} & & & & & 1 & 1 \\
\hline & $\begin{array}{l}\text { General total } \\
\text { number }\end{array}$ & 30 & 1553 & 30 & 1043 & 30 & 961 \\
\hline
\end{tabular}

